\title{
Developing Blister Rust Resistance in White Pines
}

Bohun B. Kinloch, Jr.

Additional Index words. Pinus, R ibes, Cronartium ribicola, currants, gooseberries

A fter a century since introduction to N orth America from Europe, white pine blister rust, caused by Cronartium ribicola J.C. Fisch., is recognized as one of the catastrophic plant disease epidemics in history. It has not yet stabilized and continues to spread and intensify. I ts nine native white pine hosts comprise major timber producers, important watershed protectors, keystone ecological species, and the oldest trees on earth. All are highly susceptible and some have been damaged severely in parts of their native range, as well as where they have been planted as exotics. Resistance, the most promising approach to control, requires understanding of genetic interactions between hosts and pathogen, a quest that has been ongoing for half a century. U nlike other hosts of spectacular exotic diseases, such as chestnut blight [ caused by Cryphonectria parasitica (M urrill) M .E. Barr] and dutch elm disease [caused by Ophiostoma ulmi (Buisman) $N$ annf.], white pines (PinusL.) exhibit a surprising number of resistance mechanisms to blister rust, if at only low frequencies. There are three main kinds:

- Major gene resistance (M GR), controlled bydominantgenesconditioning hypersensitive necrosis in needles, the primary infection courts, occur in at least three species. But MGR is not always as simple as it appears; epistatic interactions that affect penetrance and even dominancerelationships of $M$ endelian genes exist in some genetic backgrounds.

- Slow Rusting Resistance (SRR), isonly partial resistance, and ranges from very strong to weak. M ore complexlyinherited, it isexpressed by lower infection frequency in different trees and families, and by different kinds of bark reactions that abort infections after they establish in stem tissues.

- Ontogenetic resistance (OGR) comprises factors that confer resistance to some adult trees. It is genotype specific. OGR is very strong, but the least understood and probably most difficult mechanism to develop.

$\mathrm{O} n$ the pathogen side, estimates of population parameters of $C$. ribi cola in western $\mathrm{N}$ orth Americaindicatethat overall variability is low, with a genetically fragmented, metapopulation structure. Gene flow is also low, in spite of high outcrossing. The epidemiological unity that characterized the spread of blister rust across Europe, then to both coasts of $\mathrm{N}$ orth America, implies a corresponding genetic unity. $\mathrm{N}$ o private alleles were found in any of the western or eastern $\mathrm{N}$ orth American populations sampled, and all may share the same gene pool as the European populations from which they derive. Variation in virulence appears limited; none has been found on different $R$ ibes $L$. cultivars in extensive trials in Europe and North America, and only two racesthat neutralizemajor resistance genes in both sugar pine (P. lambertiana Dougl.) and western white pine ( $P$. monticola Dougl.) are confirmed. The one on sugar pine is evidently conditioned by a single plasmagene, an unusual phenomenon among virulence genes. Both races appear to have limited distributions.
$\mathrm{O}$ ther races may exist in $\mathrm{N}$ orth American populations, but a greater threat may lie in new introductions from Asia, the ancestral gene center of the pathogen. The specificity that exists among major genes in this noncoevolved pathosystem is intriguing. For example, major gene resistance in sugar pine is not affected by the pathogen gene for virulence to a major gene for resistance in western white pine, and vice versa. This simple complementary structure may represent a nascent gene-for-gene system. The problem for breeders, conservationists, and silviculturists is how to concentrate and deploy these various kinds of genes into synthetic or naturally selected populations that are buffered against radical racial shiftsto wider virulence in the pathogen, and so providedurable resistance. T wo basic strategies are building gene pyramids and developing multilines. We are using both of these in combination in developing resistant sugar pine.
U SD A Forest Service, Institute of Forest Genetics, Box 245, Berkeley, CA 94701.

The cost of publishing this paper was defrayed in part by the payment of page charges. U nder postal regulations, this paper therefore must be hereby marked advertisement solely to indicate this fact. 